\title{
AKAD NIKAH ULANG SEBAGAI RITUAL MEMPEROLEH KETURUNAN DALAM TINJAUAN HUKUM ISLAM (STUDI KASUS PADA PASANGAN SUAMI ISTRI DI DESA TINGGEDE KEC. MARAWOLA KAB. SIGI)
}

\author{
Moh. Rizal ${ }^{1}$, Muh. Syarif Hasyim², Sitti Nurkhaerah ${ }^{3}$ \\ ${ }^{1}$ Student Faculty of Shariah IAIN Palu, email: mohrizal14@gmail.com \\ ${ }^{2}$ Lecturer Faculty of Shariah IAIN Palu, email: mawomba@gmail.com \\ ${ }^{3}$ Lecturer Faculty of Shariah IAIN Palu, email: nurkhaerah@iainpalu.ac.id
}

\begin{abstract}
Based on the research background that has been mentioned, the remarriage agreement as a ritual of obtaining offspring in a review of Islamic law, a case study of a married couple in the village of Tinggede, Kec. Marawola Kab. Sigi, then obtained several objectives from this study, namely to explain and describe how the process of remarriage contracts for couples in the village of Tinggede Kec arawola, Kab. Sigi as a ritual to obtain offspring and how Islamic law review of the remarriage agreement to the couple in the village of Tinggede Kec.Marawola, Kab. Sigi as a ritual to get offspring. This study uses a qualitative approach with more emphasis on the relevance of the findings that occur in the field, so that the data can be presented in actual terms, the data collection technique used is the field of data collection techniques (field research). The intended data collection technique is collecting a number of data directly. The results showed that the process of implementing a marriage contract that occurred in couples in the village of Tinggede was as follows: firstly there was an underlying reason and secondly halal and haram re-marriage contracts were seen in terms of or the intention behind the process of a remarriage contract. So that in the Islamic religion, the glasses of Islamic law see this as a prohibition because of the descendants in a family, purely the gift of Allah. Humans can only endeavor, looking for reasons that are permitted by the Shari'a to get them.
\end{abstract}

Keywords: Agreement, Remarriage Agreement, Law, Shari'a

\begin{abstract}
Abstrak: Berdasarkan latar belakang penelitian yang telah disebutkan, maka akad nikah ulang sebagai ritual memperoleh keturunan dalam tinjauan hukum Islam, studi kasus pada pasangan suami istri di Desa Tinggede Kec. Marawola Kab. Sigi, maka memperoleh beberapa tujuan dari penelitian ini, yakni menjelaskan dan mendeskripsikan bagaimana proses akad nikah ulang pada pasangan di Desa Tinggede Kec.Marawola, Kab. Sigi sebagai ritual memperoleh keturunan dan bagaimana tinjauan hukum Islam terhadap akad nikah ulang pada pasangan di Desa Tinggede Kec.Marawola, Kab. Sigi sebagai ritual memperoleh keturunan. Penelitian ini menggunakan pendekatan kualitatif dengan lebih menekankan pada keteragan hasil temuan yang terjadi di lapangan, agar data tersebut dapat di sajikan secara aktual, maka teknik pengumpulan data yang digunakan adalah teknik pengumpulan data lapangan (field research). Teknik pengumpulan data yang dimaksud adalah mengumpulkan sejumlah data secara langsung. Hasil penelitian menunjukkan bahwa proses pelaksanaan akad nikah yang terjadi pada
\end{abstract}


pasangan di Desa Tinggede adalah sebagai berikut pertama adanya alasan yang mendasari dan kedua halal dan haram akad nikah ulang dilihat dari segi atau maksud yang melatarbelakangi dilakukannya prosesi akad nikah ulang. Sehingga dalam Agama Islam, kaca mata syariat Islam memandang hal ini sebagai suatu keharaman karena adanya keturunan dalam sebuah keluarga, murni pemeberian dari Allah swt. Manusia hanya bisa berikhtiar, mencari sebab yang diizinkan oleh syariat untuk mendapatkannya.

Kata kunci: Akad, Akad Nikah Ulang, Hukum, Syariat

\section{A. Pendahuluan}

Perkawinan merupakan salah satu peristiwa penting dalam kehidupan manusia. Perkawinan yang terjadi antara seorang pria dengan seorang wanita menimbulkan akibat lahir maupun batin baik terhadap keluarga masing-masing masyarakat dan juga dengan harta kekayaan yang diperoleh diantara mereka baik sebelum maupun selamanya perkawinan berlangsung. Setiap mahluk hidup memiliki hak asasi untuk melanjutkan keturunannya melalui perkawinan, yakni melalui budaya dalam melaksanakan suatu perkawinan yang dilakukan di Indonesia.

Ada perbedaan-perbedaannya dalam pelaksanaan yang disebabkan karena keberagaman kebudayaan atau kultur terhadap agama yang Setiap orang atau pasangan yang dipeluk. Setiap pasangan (laki-laki dengan perempuan) jika sudah melakukan perkawinan maka terhadapnya ada ikatan kewajiban dan hak di antara mereka berdua dan anak-anak yang lahir dari perkawinan tersebut.

Perkawinan menurut Undang-Undang Nomor 1 tahun 1974 tentang Perkawinan (selanjutnya disebut UU Perkawinan) ${ }^{1}$, bukan hanya merupakan suatu perbuatan perdata saja, akan tetapi juga merupakan suatu perbuatan keagamaan, karena sah atau tidaknya suatu perkawinan tolak ukurnya sepenuhnya.

Sasaran utama dari disyari' atkannya perkawinan dalam Islam di antaranya ialah untuk membentengi martabat manusia dari perbuatan kotor dan keji, yang telah menurunkan dan meninabobokan martabat manusia yang luhur. Islam memandang perkawinan dan pembentukan keluarga sebagai sarana efefktif untuk

${ }^{1}$ Undang-Undang Nomor 1 Tahun 1974 tentang Perkawinan (LN 1974 Nomor 1,TLN 
memelihara pemuda dan pemudi dari kerusakan, dan melindungi masyarakat dari kekacauan.

Tata cara perkawinan di Indonesia tergolong beraneka ragam antara satu dengan yang lainnya oleh karena di Indonesia mengakui adanya bermacammacam agama dan kepercayaan, yang tata caranya berbeda. Hal yang demikian dimungkinkan dalam Negara Republik Indonesia yang berdasarkan Pancasila yang dengan tegas mengakui adanya prinsip kebebasan beragama. ${ }^{2}$ Pasangan suami-istri yang telah melangsungkan perkawinan, pada umumnya ingin memiliki keturunan dari perkawinan yang telah mereka lakukan, tetapi ada pula pasangan suami istri yang hidup bersama tanpa keinginan untuk mendapatkan keturunan.

Sebelum lahirnya UU Perkawinan, mengenai ketentuan, tatacara dan sahnya suatu perkawinan bagi orang Indonesia pada umumnya didasarkan pada hukum agama dan hukum adat masing-masing. Menurut hukum adat, perkawinan adalah suatu ikatan antara seorang laki-laki dengan seorang perempuan untuk membentuk rumah tangga yang dilaksanakan secara adat dan agamanya dengan melibatkan keluarga kedua belah pihak saudara maupun kerabat. Setelah berlakunya UU Perkawinan, maka terjadi unifikasi hukum dalam perkawinan di Indonesia, dimana perkawinan mempunyai hubungan yang sangat erat dengan agama/kerohanian. Pengaturan hukum tentang perkawinan telah berlaku sama terhadap semua warga Negara oleh karena itu, setiap warga negara harus patuh terhadap hukum yang berlaku, termasuk terhadap UU Perkawinan yang menjadi landasan untuk menciptakan kepastian hukum, baik dari sudut hukum keluarga, harta benda, dan akibat hukum dari suatu perkawinan. ${ }^{3}$

Jadi, Perkawinan sebagai salah satu ajaran Islam merupakan sesuatu ketetapan Allah atas segala mahluk, di tinjau dari segi ibadah, dengan perkawinan berarti telah melaksanakan sunnah nabi. Rasululah juga memerintahkan agar orang-orang yang telah mempunyai kesanggupan untuk segera melakukan pernikahan karena hal itu dapat mencegah dari hal-hal yang dilarang oleh Allah. Selain hal diatas perkawinan dapat menjaga populasi mahluk hidup, yakni dengan

${ }^{2}$ Subekti, Hukum Keluarga dan Hukum Waris, (Jakarta: Penerbit PT.Intermasa, 2002), 1.

${ }^{3} \mathrm{~K}$. Wantjik Saleh, Hukum Perkawinan Indonesia, (Jakarta Timur: Ghalia Indonesia, 1982), 3 
berlangsungnya perkawinan maka akan menjaga keturunan agar terus berlangsung sampai hari kiamat. Namun tidak semua perkawinan yang dilakukan oleh pria dan wanita mampu melahirkan keturunan, betapa banyak kita lihat ada pasangan yang sudah menikah selama beberapa tahun bahkan sampai usia lanjut belum dikaruniai keturunan oleh Allah swt, ini menunujukan persoalan keturunan merupakan ketetapan Allah, manusia hanya bisa berusaha dalam menggapai itu melalui jalan pernikahan akan tetapi hasilnya ditentukan oleh Allah swt.

Sebagaimana telah disebutkan di atas Indonesia merupakan negara yang mempunyai kultur/budaya majemuk, maknanya di Indonesia banyak berkembang berbagai macam kepercayaan dalam segala hal, terlepas dari kepercayaan megenai agama ada kepercayaan mengenai adat leluhur, salah satunya dari segi perkawinan di mana jika dalam perkawinan pasangan suamiistribelum dikaruniai keturunan maka ada kepercayaan pernikahan itu harus diperbaharui akad nikahnya, atau dengan kata lain dinikah ulang, kepercayaan ini berkembang di sebagian masyarakat suku Kaili yang ada di Sulawesi Tengah yang bermukim di Kota Palu khusunya di Kabupaten Sigi Biromaru. Dari persoalan ini bagaimana kaca mata hukum Islam memandang hal tersebut, apakah merupakan suatu kebolehan atau tidak, untuk pelaksanaan akad nikah ulang sebagai ritual memperoleh keturunan

Untuk itu, penelitian ini bertujuan untuk menjelaskan kaca mata hukum Islam memandang hal tersebut, apakah merupakan suatu kebolehan atau tidak untuk melaksanakan akad nikah ulang sebagai ritual memperoleh keturunan. Dan penelitian ini menggunakan pendekatan kualitatif dengan lebih menekankan pada keterangan hasil temuan yang terjadi di lapangan, agar data tersebut dapat disajikan secara aktual. Maksud dan alasan yang mendasar penelitian ini menggunakan pendekatan metode kualitatif karena lebih bersifat kealamiahan sebuah data atau sebuah metode yang menyelidiki kondisi yang objektif dengan maksud memperoleh data lapangan yang di anggap cukup objektif dalam menguraikan dan menganalisis hasil penelitian.

\section{B. Pembahasan}

\section{Akad Nikah Ulang dalam Hukum Islam}


Nikah ulang atau diistilahkan tajdidun nikah adalah Tajdid menurut bahasa adalah pembaharuan atau memperbaharui. ${ }^{4}$ Dalam kata tajdid mengandung arti yaitu membangun kembali, menghidupkan kembali, menyusun kembali, atau memperbaikinya sebagaimana yang diharapkan.

Pembaharuan disini adalah memperbarui nikah, dengan arti sudah pernah terjadi akad nikah yang sah menurut syara', kemudian dengan maksud sebagai ihtiyath (hati-hati) dan membuat kenyamanan hati maka dilakukan dilakukan akad nikah sekali lagi atau lebih. Secara Etimologi kata Tajdiidun Nikah, berasal dari kata, Jaddada - Yujaddidu - Tajdiidan yang artinya pembaharuan. Yang dimaksud pembaharuan disini adalah memperbaharui nikah. Kata nikah berasal dari kata nakaha - yankihu - nikaha yang berarti Nikah. ${ }^{5}$

Namun masyarakat luas sering menyebut dengan Istilah Tajadud. Tajaddud berasal dari bahasa arab, dari kata tajaddada - yutajaddadu - tajaddudan yang artinya memjadi baru lagi. Konsep Tajaddud ini sering kali dipakai oleh masyarakat dalam hal memperbaharui nikah. Menurut bahasa Nikah berarti "menghimpun dan ngumpulkan". Dalam pengertian fikih "Nikah adalah akad yang mengandung kebolehan melakukan hubungan suami istri dengan lafal nikah/kawin atau yang semakna dengan itu. Dalam pasal 2 (dua) Kompilasi Hukum Islam disebutkan bahwa:

Perkawinan menurut hukum Islam adalah pernikahan yaitu akad yang kuat atau mitsaqongholidhon untuk menaanti perintah Allah dan melaksanakannya adalah Ibadah. ${ }^{6}$

Ta’rif perkawinan menurut Sulaiman Rasyid, Ialah akad yang menghalalkan pergaulan dan membatasi hak dan kewajiban serta bertolongtolongan antara seorang laki-laki dan seorang perempuan yang antara keduannya bukan muhrim. ${ }^{7}$

${ }^{4}$ Masduki mahfuz, Bahsul masail, (Malang: ppsnh, 2000), 52.

${ }^{5}$ Ibid.

${ }^{6}$ Kompilasi Hukum Islam, (Jakarta :Depag RI 2000 ), 20.

${ }^{7}$ Sulaiman Rasyid, Ilmu fiqhi, (Jakarta :Cv toha 1980), 57. 
Dari uraian tersebut diatas tampak jelas bahwa yang dimaksud dengan tajdid nikah dalam pernikahan adalah pembaharuan akad nikah atau memperbaharui Akad Nikah atau mengulang Akad Nikah.

2. Proses Pelaksanaan Akad Nikah Ulang di Desa Tinggede Kec. Marawola, Kab. Sigi

Sesuai dengan pengertian tajdid nikah adalah memperbarui ikatan pernikahan yang dilakukan oleh suami istri yang masih sah, setalah mengalami pergeseran dari harapan pernikahan dan merupakan tindakan kehati-hatian untuk membina keluarga yang harmonis sesuai dengan harapan.

Deskripsi tentang pelaksanaan akad nikah ulang pada pasangan Desa Tinggede dapat diketahui dari hasil pengamatan dan wawancara yang di lakukan .

Adapun proses pelaksanaan akad nikah yang terjadi pada pasangan di Desa Tinggede adalah sebagai berikut pertama adanya alasan yang mendasari sehingga adanya pelaksanaan akad nikah ulang seperti pada kasus pasangan suami istri yang ada di desa Tinggede yang mendasari sehingga terjadinya akad nikah ulang adalah kedua pasangan yang sudah lama melangsungkan pernikakan tetapi belum juga dikaruniai seorang anak. ${ }^{8}$

Tokoh adat atau keluarga pasangan suamiistriyang melakukan akad nikah ulang berkeyakinan bahwa yang terjadi diantara mereka disebabkan oleh akad nikah yang pertama kurang maksimal sehingga harus dilakukan akad yang kedua dan terbukti setelah akad nikah kedua dilakukan tidak lama kemudian pasangan suami istri ini dikarunia seorang anak, kepercayaan yang berkembang di masyarakat pada umumnya maupun di keluarga pasangan pada khususnya adalah pada akad nikah yang pertama keluarga lupa menziarahi kuburan orang-orang tua yang telah meninggal dan membacakan doa tahlil kepada mereka. ${ }^{9}$

Menurut Farid sebagai akad nikah ulang dilakukannya yaitu dengan alasan sudah beberapa tahun dia dan pasangannya melangsungkan pernikahan tapi tidak diberi keturunan, maka keluarga sepakat untuk melakukan akad nikah ulang dengan harapan setelah akad nikah ulang farid dan isterinya diberi keturunan.

\footnotetext{
${ }^{8}$ Wawancara kepada Farid, 05 Agustus 2017

${ }^{9}$ Wawancara kepada Fani, 05 Agustus 2017
} 
Tidak lama dari itu selang beberapa bulan istri Farid yang bernama Fani mengandung dan melahirkan seorang anak. ${ }^{10}$

Menurut tokoh adat pak syamsu tata cara akad nikah ulang yang dia lakukan tidak dimulai lagi dengan acara lamaran lagi , Farid dan istri langsung melakukan ijab qabul layaknya penikahan biasa, akadnya pun sama seperti biasa dengan menghadirkan wali dan saksi, dan setelah akad tersebut dibaca doa tahlil untuk mendoakan orang-orang tua yang telah meninggal. ${ }^{11}$

Sesuai dengan pengertian akad nikah ulang adalah memperbarui ikatan pernikahan yang dilakukan oleh suami istri yang masih sah, setalah mengalami pergeseran dari harapan pernikahan dan merupakan tindakan kehati-hatian untuk membina keluarga yang harmonis sesuai dengan harapan.

Deskripsi tentang pelaksanaan akad nikah ulang pada masyarakat Desa Tinggede dapat diketahui dari hasil pengamatan, adapun proses pelaksanaan tajdid al-nikah yang terjadi dikalangan pelaku akan nikah ulang di Desa Tinggede adalah sebagai berikut:

Pertama, pasangan suami istri yang akan melakukan akad nikah ulang datang ke rumah tokoh agama yang bersedia menjadi penghulu dalam akad nikah ulang yang mereka lakukan dan menanyakan syarat-syarat yang dibutuhkan dalam akad nikah ulang. Kedua, pasangan suami istri tersebut telah menyiapkan sebelumnya rukun dan syarat pernikahan sebagaimana yang pertama, hanya saja dalam pelaksanaan tajdid al-nikah diketahui oleh keluarga terdekat saja dan tidak mengundang orang umum. Ketiga, khutbah nikah oleh pengulu dengan mengunakan bahasa arab dan Indonesia, kemudian pelaksanaan Ijab dan Qabul yang disertai dengan penyerahan mahar dari suami kepada istrinya. Keempat, atau yang terakhir yaitu doa yang dipimpin langsung oleh penghulu dan akhirnya dengan acara atau makan bersama di tempat dilaksankan akad nikah ulang yakni di rumah istrinya. ${ }^{12}$

\footnotetext{
${ }^{10}$ Wawancara kepada Farid, 05 Agustus 2017

${ }^{11}$ Wawancara kepada tokoh adat Pak Syamsu, 06 Agustus 2017

${ }^{12}$ Wawancara kepada Farid, 05 Agustus 2017
} 


\section{Tinjauan Hukum Islam Terhadap Akad Nikah Ulang pada Pasangan} di Desa Tinggede Kec. Marawola, Kab. Sigi Sebagai Ritual Memperoleh Keturunan

Islam adalah agama yang syamil mengatur seluruh bentuk kehidupan umat manusia sejak dari zaman azali hingga hari akhirat kelak. Dari sekian banyak persoalan kehidupan umat manusia masalah perkawinan adalah hal yang sangat urgen dan banyak dibicarakan dalam hidup dan kehidupan umat manusia, karena manusia dilahirkan dalam keadaan berpasang-pasangan sebagaimana halnya dengan berbagai makhluk-makhluk Allah swt lainnya, sesuai dengan firman Allah swt. dalam Al-Quran Surah Adz-Dzariyat ayat [51]: 49:

Terjemahnya:

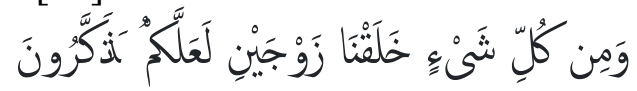

Dan segala sesuatu Kami ciptakan berpasang-pasangan supaya kamu mengingat kebesaran Allah. ${ }^{13}$

Seluruh apa yang diciptakan oleh Allah swt. pasti ada tujuan dan hikmahnya masing-masing. Dalam pembahasan yang sederhana ini penulis akan mengemukakan tentang tujuan dan hikmah perkawinan dalamm Islam, agar setiap insan yang bermaksud melaksanakan perkawinan dapat memahami dengan jelas tujuan dan hikmah akad nikah yang akan dijalaninya, sehingga ia lebih berhatihati dalam mengarungi bahtera rumah tangganya. Oleh karenanya dengan kehatihatian dalam menjalani hidup berumah tangga akan selalu terjalin kerukunan, ketenangan dan ketenteraman dalam dalam membina rumah tannga sehingga tercipta hidup bahagia dan sejahtera sebagai rumah tangga yang terbangun di atas pondasi keimanan dan ketaqwaan yang akan melahirkan terwujudnya keluarga sakinah mawaddah warahmah.

Akad nikah ulang termasuk jenis permasalahan dalam lingkup ijtihad yang tidak ada ketentuan secara pasti baik dalam Al-Quran maupun Sunnah. Oleh sebab itu, tidak dihindari dari pro dan kontra tentang peermasalahan tersebut. Maka sebagaimana landasan atau pijakan hukum yang dipakai pelaku akad nikah ulang adalah mengambil kebiasaan yang sudah menjadi tradisi pada perorangan 2012), 522 .

${ }^{13}$ Al-Qur'an dan Terjemahannya (Mushaf Fatimah), (Jakarta: PT. Insan Media Pustaka, 
tertentu saja dengan tujuan memperbarui nikah yang terdahulu demi terciptanya keluarga yang lebih harmonis.

Adapun faktor-faktor yang melatar belakangi dilaksanakanya akad nikah ulang:

Faktor ekonomi dan sosial yang mengakitbatkan terjadinya pertengkaran. Kepercayaan yang mendasar pada masyarakat bahwasanya jika suatu keluarga itu tidak harmonis dan pertengkaran sering terjadi maka rizki yang diberikan oleh sang pencipta pun ikut seret dan macet.

Bertolak dari pemahaman seperti ini jika ditinjau dari segi hukum Islam yang pada hakikatnya menarik manfaat maka akad nikah ulang didasari niatan semacam ini tidaklah Benar karena rizki, anak datangnya dari Allah bukan dari akad nikah ulang dengan kepercayaan tertentu yang telah dilakukan. Akan tetapi, karena guna menjaga tali pernikahan agar tidak terjadi perceraian dan mendatangkan manfaat yaitu menyelamatkan keluarga tetap utuh dan menjadikan keluarga lebih harmonis maka perlu dilakukan akad nikah ulang bagi pasangan yang masih sah untuk tujuan memperindah atau memperbarui pernikahan.

Imam Muhammad izzuddin bin Abdus Salam menegaskan bahwa tujuan pokok syariat Islam adalah menolak kerusakan dan menarik kemaslahatan. Lebih lanjut ditegaskan bahwa tujuan pokok syariat Islam adalah mewujudkan keadilan dan menarik kemaslahatan. Seperti yang menjadi dasar kaida asasiyah yaitu menolak kerusakan dan menarik kemaslahatan. ${ }^{14}$

Untuk kehati-hatian dalam berumah tangga baik dalam ucapan ataupun perbuatan.

Diharapkan bisa memperoleh keturunan.

Adapun pendapat suatu aliran kepercayaan suku kaili, bahwa jika dari suatu pernikahan tidak dilahirkan seorang anak, maka si suami dan si istri harus memperbarui pernikahanya dengan harapan agar dengan pemilihan hari yang lebih tepat, anak keturunan dapat dilahirkan.Sebuah proses pelasanaan akad nikah ulang yang terjadi di Desa Tinggede sebagaimana yang telah dipaparkan di atas

${ }^{14}$ Muchlis Usman, Kaidah-Kaidah Ushuliyah dan Fiqhiyah, (Jakarta: PT. Raja Grafindo Persada: 1999), 24 
memang sudah menjadi sebuah tradisi yang berjalan secara turun temurun dan sudah menjadi kepercayan masyarakat itu sendiri. Secara hukum agama bahwa adanya akad nikah ulang termasuk kategori Mubah selama tidak menyimpang dari apa yang telah diajarkan dalam Islam sendiri terutama mengenai prosesinya. Namun hal ini ketika di analisis ulang maka bisa kembali ke kaidah fiqhiah yang berbunyi "yang sudah yakin tidak dapat dihapuskan oleh keraguan". ${ }^{15}$

Untuk menentukan halal atau haram, maka kita harus kembali pada prinsip-prinsip yang ada dalam ajaran Islam. Prinsip halal dan haram dalam Islam terbagi menjadi tiga bagian yakni masalah ibadah, adat dan muamalat. Ada kaidah-kaidah fikih yang berbeda diantara ketiga hal tersebut antara lain: ${ }^{16}$

a. Sudut pandang ibadah

Dalam sudut pandang ibadah berlaku kaidah bahwasanya "Suatu ibadah tidak disyariatkan kecuali disyariatkan oleh Allah". Sedangkan Hukum Asal Ibadah dinyatakan bahwa Hukum asal dalam masalah ibadah adalah tauqif (mengikuti ketentuan dan tata cara yang telah ditentukan oleh syariat). Karena itu tidak dibenarkan beribadah kepada Allah kecuali dengan peribadatan yang telah disyariatkan oleh Allah dalam Kitab-Nya dan melalui penjelasan Rasul-Nya, Muhammad saw. Hal ini karena ibadah adalah hak murni Allah yang ia tuntut dari hamba-Nya berdasarkan sifat rububiyah-Nya terhadap mereka. Tata cara, sifat, dan ber-taqorub (melakukan pendekatan diri kepada Allah) dengan ibadah hanya boleh dilakukan dengan cara yang telah disyariatkan dan diizinkan-Nya.

Untuk melaksanakan Ibadah harus ada perintah, karena masalah ibadah itu semata-mata urusan agama yang tidak ditetapkan melainkan dari jalan wahyu. Atau dalam bahasa lain sebagaimana dikatakan oleh Ibnu Taimiyah bahwa ibadah yang diwajibkan dan dicintai Allah tidak dapat ditunaikan kecuali dengan syariat.

Adapun masalah pernikahan adalah bagian dari ibadah, sebab di dalamnya ada perintah ada larangan serta ada tata cara, syarat dan rukun di dalam melaksanakan perkawinan. Sedangkan istilah akad nikah ulang atau pembaharuan

\footnotetext{
2003), 95

${ }^{15}$ Ali Afandi, Hukum Waris, Hukum Keluarga, Hukum Pembuktian, (Jakarta: Prenada,

${ }^{16}$ Ibid, 15
} 
nikah didalam ajaran Islam tidak dikenal. Dan juga tidak pernah ada perintah ataupun petunjuk dari Allah maupun Rasul-Nya, mengenai pelaksanaan akad nikah ulang Sesuai dengan kaidah fikih dan hukum asal ibadah sebagaimana yang telah dijelaskan dapat disimpulkan bahwa hukum melaksanakan akad nikah ulang atau pembaharuan nikah ditinjau dari kaca mata ibadah adalah "haram" ${ }^{17}$ Dan termasuk perbuatan yang mengada-ngada serta membuat tata cara baru dalam masalah ibadah, yang jelas-jelas dilarang oleh Rasulullah saw. Sebagaimana sabda Rasulullah: Barangsiapa yang membuat cara baru dalam urusan kami, dengan sesuatu yang tidak ada contohnya, maka dia tertolak".

Ini karena hakikat agama tercermin dalam dua hal yaitu yang pertama, tidak beribadah kecuali kepada Allah, dan kedua, tidak beribadah kepada Allah kecuali dengan petunjuk syariat-Nya. Barangsiapa membuat-buat sendiri cara beribadah siapapun dia maka hal itu termasuk kesesatan yang tertolak. Demikian itu dikarenakan Allah sendirilah yang berhak untuk menggariskan tata cara beribadah yang dengan ibadah itu diharapkan manusia dapat lebih bertaqarub (mendekatkan) diri kepada-Nya.

b. Sudut pandang muamalat

Dalam muamalat berlaku kaidah bahwa asal segala sesuatu itu adalah halal. Tidak ada yang haram kecuali jika ada nash (dalil) yang shohih (tidak cacat periwayatanya) dan sharih (jelas maknanya) dari pemilik syariat (Allah swt.) yang mengharamkannya. ${ }^{18}$

c. Sudut pandang adat

Kaidahnya menyatakan bahwa dalam persoalan adat pada prinsipnya segala sesuatu itu boleh untuk dikerjakan, kecuali yang memang telah diharamkan. Maka dengan hal ini menggunakan kaidah fiqh sebagai berikut:

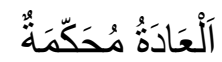

\footnotetext{
${ }^{17}$ Abdul Wahab Khallaf, Kaidah Kaidah Hukum Islam, Cet III , (Jakarta: PT. Raja Grafindo Persada: 2000), 130.

${ }^{18}$ Ibid. 132.
} 
Artinya:

Adat kebiasaan dapat ditetapkan sebagai hukum. ${ }^{19}$

1) Adat dapat diterima jika memenuhi syarat sebgai berikut:

2) Perbuatan yang dilakukan logis dengan akal sehat, syarat ini menunjukkan bahwa adat tidak mungkin berkenaan dengan perbuatan maksiat.

3) Perbuatan perkara yang dilakukan secara terulang-ulang boleh dikata sudah mendarah daging pada perilaku masyarakat.

4) Tidak bertengtangan dengan ketentuan nash, baik al-Quran maupun Sunah.

5) Tidak mendatangkan kemadhorotan serta sejalan dengan jiwa akal yang sejahtera.

Sebagaimana disampaikan oleh Ibnu Taymiyah bahwa adat istiadat itu adalah sesuatu yang biasa dilakukan oleh masyarakat dalam urusan dunia yang mereka butuhkan. Prinsip dasar hukumnya adalah tidak ada larangan. Tidak ada larangan padanya kecuali apa-apa yang dilarang Allah Swt. Demikian itu karena, perintah dan larangan adalah kewenangan syariat Allah swt.

Adapun mengenai adat dan Muamalat, berlaku kaidah fikih bahwa asal segala sesuatu adalah boleh kecuali ada nash yang melarangnya. Karena sumber masalah adat dan mu'amalat bukan dari syar'i (Allah), tetapi justru manusia itu sendiri yang menimbulkan dan mengadakan.Syar'I dalam hal ini tugasnya adalah untuk membetulkan dan meluruskan, mendidik dan mengakui kecuali dalam beberapa hal yang memang akan membawa kerusakan dan madorot.

Dari beberapa keterangan yang kami himpun melalui berbagai sumber dapat kami tarik suatu kesimpulan bahwa akad nikah ulang atau pembaharuan nikah itu memang lebih condong kepada tradisi atau adat. ${ }^{20}$ Yakni tradisi yang sudah turun temurun dalam rangka untuk memperbaharui nikah. Yang dilakukan ketika pasangan Suami Istri ada suatu masalah didalam kehidupan rumah tangga mereka. Mungkin lebih tepat jika dikatakan bahwa Istilah nikah ulang yang mereka gunakan itu sebenarnya menurut bahasa Al-quran adalah Rujuk. Namun jika dilihat dari maksud dan tujuan melaksanakan akad nikah ulang, maka tidak

\footnotetext{
${ }^{19}$ Abdul Mudjib, Kaidah-Kaidah Ilmu Fiqih, (Jakarta: kalam Mulia, 2001), 19.

${ }^{20}$ Ibid. 32
} 
semuanya bisa diartikan sebagai istilah Rujuk. Karena itulah untuk menetukan Hukum melaksanakan akad nikah ulang sebagai suatu tradisi juga harus melihat maksud dan tujuan dilaksanakannya akad nikah ulang akad nikah ulang merupakan tindakan sebagai lambang membuat kenyamanan hati dan ikhtiar (kehati-hatian) yang diperintah dalam agama sebagaimana kandungan sabda Nabi Muhammad saw: Yang halal itu jelas dan yang haram itu jelas. Dan diantara keduanya terdapat hal mutasyabihat/ samar-samar, yang tidak diketahui oleh kebanyakan manusia. Maka barang siapa yang menjaga hal-hal musyabihat maka ia telah membersihkan agama dan kehormatannya. (H.R Bukhari). ${ }^{21}$

Menurut Sayyid Abdurrahman dalam kitabnya yang berjudul Bughyah almustarsyidin, memberikan pemaknaan tentang akad nikah ulang adalah sebagai berikut: Telah menikahkan sebagaian wali terhadap keluarganya dengan tidak ada kesepadanan dengan kerelaan orang- orang yang ada ditingkatnya, kemudian suami mencela istrinya dan istrinya Menghendaki tajdid dari suaminya, maka harus ada kerelaan dari semuanya. Menurut pendapat yang kuat dan tidak cukup dengan kerelaan sebelumnya dan yang menyamainya qodhi (hakim) ketika tidak adanya wali, meskipun diperbaharui dengan orang yang rela pada wali pertama tetapi tajdid itu lebih utama dicegah sebagai wali-wali. ${ }^{22}$

Dari keterangan di atas bisa dipahami bahwa hukum dari akad nikah ulang itu boleh dilaksanakan. Pelaksanaan akad nikah ulang diperbolehkan dengan syarat harus adanya kerelaan antara suami dan istri. Menurut Ibnu Munir, beliau memberikan suatu hukum dari akad nikah ulang adalah boleh, karena mengulangi lafad akad nikah dalam nikah yang kedua tidak merusak pada akad yang pertama. $^{23}$ Kemudian dikuatkan oleh argument Ahmad bin Ali bin Hajar Alasqolani, menyatakan bahwa menurut jumhur ulama bahwa akad nikah ulang tidak merusak akad yang pertama. Dan beliau juga menambahi perkataan bahwa

\footnotetext{
${ }^{21}$ Bukhari, Shahih Bukhari, (Maktabah Syamilah, Juz.I, No. Hadis 52), 20.

${ }^{22}$ Abdurrahman Bin Muhammad Bin Hasan bin Umar, Bughya Al-Mustarsyidi, (PT. Darul khaya', tth), 209.

${ }^{23}$ Yusuf al-ardabili al-syafii, Al-anwar, juz II, (Dar al-dhiya'), h. 441
} 
yang shahi disisi ulama Syafi'iyah adalah mengulangi akad nikah atau akad lainya tidak mengakibatkan fasahk akad petama, sebagaiman pendapat jumhur ulama. ${ }^{24}$

Akan tetapi ada juga ulama Syafiiyah yang berpendapat bahwa akad nikah ulang dapat membatalkan nikah sebelumnya antara lain Yusuf al-ardabili al syafii, ulama terkemuka mazhab Syfiih (wafat $779 \mathrm{H}$ ) sebagaimana perkataan beliau dalam kitabnya al-anwar li A'mal sebagai berikut: Jika seorang suami memperbarui nikah kepada istrinya, maka wajib memberi mahar lain, karena ia mengakui perceraian dan memperbarui nikah termasuk mengurangi hitungan talak kalau dilakukan sampai tiga kali maka diperlukan muhallil(kawin rekayasa). ${ }^{25}$

Menurut A. Masduki Machfudh hukum dari akad nikah ulang adalah boleh dan tidak merusak pada akad yang terjadi, karena memperbarui akad itu hanya sekedar keindahan atau berhati-hati. Hal ini juga diungkapkan oleh A. Qusyairi Ismail, bahwa hukum asal memperbarui akad nikah itu boleh karena bertujuan hati-hati, agar terhindar dari hal yang tidak diinginkan atau bertujuan tajammul (upaya menaikkan prestise/ menjaga gengsi). ${ }^{26}$

Bagi semua pasangan suami istri pasti menginginkan suatu keluarga yang bahagia sakinah mawaddah warohmah baik bahagia dunia sampai akhirat akan tetapi dalam perjalanan rumah tangga tidak terlepas dari yang pernah terjadi pada rumah tangga mereka itu bisa merusak tali pernikahan yang selama ini ingin dipertahankan keutuhanya. Adapun rasa was-was tentang status pernikahan yang masih utuh atau sudah putus karena terlontar kata-kata yang mengandung arti talak secara tidak sengaja, maka lebih baiknya memperbaiki pernikahan dengan akad nuikah ulang guna rasa aman dan menghilangkan keragu-raguan Karena sangatlah tidak mungkin rumah tangga bisa dibangun dan berjalan mulus jika dihantui perasaan pernah mengucapkan kata talak secara tidak sengaja. Hal ini sejalan dengan hadis Nabi Muhammad saw., yang artinya "tinggalkanlah apa-apa yang meragukanmu, kerjakanlah apa-apa yang tidak meragukanmu”. (HR. anNasa'i)

\footnotetext{
${ }^{24}$ Ibid

${ }^{25}$ Ibid.

${ }^{26}$ Masduki Machfudh, Bahstuln Masa'il diniyah, (Malang: PPSH, 2000), 25
} 
Adanya akad nikah ulang guna memperbarui dan memeperindah sebuah pernikahan yang sudah menjadi sebagaian masyarakat kalil dan merupakan sebagai salah satu solusi atau jalan keluar untuk menghindari hal yang buruk dalam berumah tangga dan memperkuat tali pernikahan adalah hukum yang harus dijaga kemaslahatanya dan masuk dalam maslahah mursalah. Terutama dimana syari' tidak menyariatkan hukum untuk mewujudkan maslahat itu, juga tidak ada terdapat dalil yang menunjukan atas pengakuannya dan pembatalannya. ${ }^{27}$ Adapun marsalah mursalah dalam akad nikah ulang adalah merupakan kenyataan baru yang datang setelah terputusnya wahyu. Yang tidak ada nash yang secara jelas melarang dan tidak ada nash yang memerintahkanya maupun membatalkanya. Jadi kemaslahtan yang ada pada tajdid al-nikah adalah terciptanya keluarga yang sakinah mawaddah warahmah dan terhindar dari perceraian yang bisa nmngakibatkan terlantarnya anak-anak mereka.

Sebagaimana telah dijelaskan bahwa menentukan halal dan haram akad nikah ulang dilihat dari segi atau maksud yang melatarbelakangi dilakukannya prosesi akad nikah ulang. Adapun prosesi akad nikah ulang yang dilakukan oleh satu pasangan di Desa Tinggede tujuannya untuk memperoleh keturunan hal ini berarti berkenaan dengan suatu persoalan keyakinan yang menjadi ushul dalam agama Islam, kaca mata syariat Islam memandang hal ini sebagai suatu keharaman karena adanya keturunan dalam sebuah keluarga, murni pemeberian dari Allah swt. manusia hanya bisa berikhtiar, mencari sebab yang di izinkan oleh syariat untuk mendapatkannya, ${ }^{28}$ Allah berfirman dalam surah As-syura [42] : 4950:

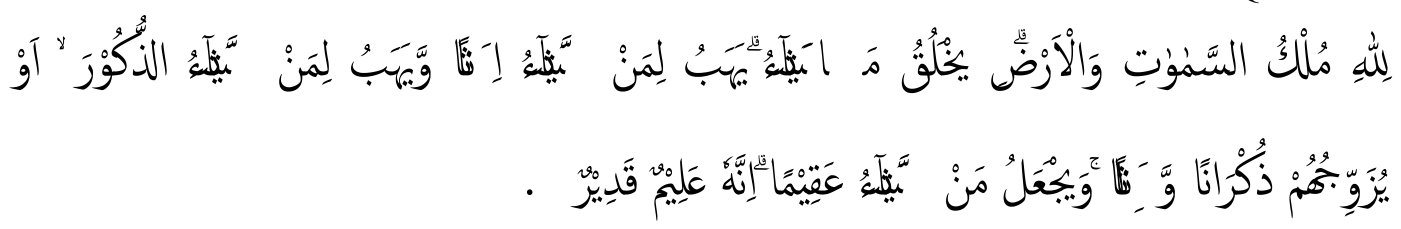

${ }^{27}$ Abdul Wahab Khallaf, Kaidah-Kaidah Fiqhi Islam, Cet III, (Jakarta: PT. Raja Grafindo Persada, 2000), 123.

${ }^{28}$ Syeikh ustaimin, Majmu’ Fatawa Lajnah Daimah, (Madinah, 1992), 20951. 
Terjemah:

atau Dia menganugerahkan jenis laki-laki dan perempuan, dan menjadikan mandul siapa yang Dia kehendaki. Dia Maha Mengetahui, Mahakuasa.

Terjemah:

Milik Allah-lah kerajaan langit dan bumi; Dia menciptakan apa yang Dia kehendaki, memberikan anak perempuan kepada siapa yang Dia kehendaki dan memberikan anak laki-laki kepada siapa yang Dia kehendaki,

Terjemahnya:

Kepunyaan Allah-lah kerajaan langit dan bumi, Dia menciptakan apa yang Dia kehendaki. Dia memberikan anak-anak perempuan kepada siapa yang Dia kehendaki dan memberikan anak-anak lelaki kepada siapa yang Dia kehendaki. Atau Dia menganugerahkan kedua jenis laki-laki dan perempuan (kepada siapa) yang dikehendaki-Nya, dan Dia menjadikan mandul siapa yang Dia kehendaki. Sesungguhnya Dia Maha mengetahui lagi Maha Kuasa. ${ }^{2}$

Memahami hal ini yang bisa dilakukan oleh manusia hanya berikhtiar, mencari sebab yang diizinkan syariat untuk mendapatkan anak semacam berdoa dan berobat ke dokter terkait. Ada kaidah penting terkait penggunaan sebab, kaidah itu menyatakan mengambil sesuatu sebagai sebab, padahal itu bukan sebab, termasuk kesyrikan, Ibnu Tayyimah mengatakan tidak boleh seorang berkeyakinan bahwa ada sesuatu yang merupakan sebab naumun tidak diketahui. Siapa yang menetapkan sesuatu sebagai sebab tanpa ilmu atau bertentangan dengan syariat berarti dia melakukan kebatilan.sebagaimana orang menganggap bahwa nazar merupakan sebab dihilangkannya bencana. ${ }^{30}$

Untuk bisa memahami apakah benda itu bisa menjadi sebab ataukah bukan ada dua kriteria lahir secara syariat. Jika terpenuhi salah satu dari kriteria ini, maka terpenuhi persyaratan untuk dijadikan sebab.

Pertama, adalah perkara tersebut ada dalilnya, Allah tetapkan sesuatu sebab tersebut melalui wahyu yang disampaikan kepada Nabi saw. Sebab model ini diistilahkan dengan sebab syar'i. Itulah sebab yang ditetapkan berdasar dalil 2012), 488

${ }^{29}$ Al-Qur'an dan Terjemahannya (Mushaf Fatimah), (Jakarta: PT. Insan Media Pustaka,

${ }^{30}$ Ibnu tayymiyah, al-Mustadrak 'ala Fatawa Syaikhil Islam, (Beirut: Darul Fikri, 1987), 46. 
baik Alqur'an maupun Sunnah, meskipun sabab itu tidak masuk dalam lingkup penelitian ilmiah. Kedua, terbukti secara empirik dan masuk akal. Artinyan sebab tersebut merupakan bagian dari hasil hasil pengalaman atau penelitian ilmiah yang menyatakan bahwa sesuatu tersebut merupakan sebab munculnya sesuatu yang lain. Misalnya makan adalah sebab kenyang, belajar merupakan sebab mendapatkan Ilmu, bekerja dapat menghasilkan pendapatan dan lain sebagainya, atau sebab berdasarkan penelitian, semacam listrik menjadi sebab lampu menyala, atau obat yang dapat menghilangkan nyeri, kriteria seperti ini sering disebut sebab kauni.

Berdasarkan hal tersebut maka dapat disimpulkan bahwa ada atau tidak adanya keturunan tidak tergantung pada pengulangan akad nikah karena akad nikah hanya di laksanakan jika pasangan tersbut belum menikah dan mampu memenuhi syarat dan rukun nikah berdasarkan hukum Islam.

\section{Penutup}

Dari uraian di atas, maka dapat diambil kesimpulan bahwa adapun mengenai proses pelaksanaan akad nikah yang terjadi pada pasangan di Desa Tinggede adalah sebagai berikut Pertama, pasangan suami istri yang akan melakukan akad nikah ulang datang kerumah tokoh agama yang bersedia menjadi penghulu, kedua pasangan suami istri tersebut telah menyiapkan sebelumnya rukun dan syarat pernikahan, ketiga khutbah nikah oleh pengulu, dan kemudian pelaksanaan ijab dan qabul yang disertai dengan penyerahan mahar dari suami kepada istrinya. Keempat atau yang terakhir yaitu doa yang dipimpin langsung oleh penghulu dan akhirnya dengan acara atau makan bersama di tempat dilaksankan akad nikah ulang yakni di rumah istrinya. Dan Adapun prosesi akad nikah ulang yang dilakukan oleh satu pasangan di Desa Tinggede tujuannya untuk memperoleh keturunan hal ini berarti berkenaan dengan suatu persoalan keyakinan yang menjadi ushul dalam agama Islam, kaca mata syariat Islam memandang hal ini sebagai suatu keharaman karena adanya keturunan dalam sebuah keluarga, murni pemeberian dari Allah swt. manusia hanya bisa berikhtiar, mencari sebab yang di izinkan oleh syariat untuk mendapatkannya. 


\section{DAFTAR PUSTAKA}

Al-Qur'an dan Terjemahannya (Mushaf Fatimah), Jakarta: PT. Insan Media Pustaka, 2012.

Abdurrahman Bin Muhammad Bin Hasan bin Umar, Bughya Al-Mustarsyidi, PT. Darul khaya', th.

Ali Afandi, Hukum Waris, Hukum Keluarga, Hukum Pembuktian, Jakarta: Prenada, 2003.

Al-syafii, Yusuf al-ardabili, Al-anwar, juz II, Dar al-dhiya’.

Bukhari, Shahih Bukhari, Maktabah Syamilah, Juz.I, No. Hadis 52.

Dawud, Ibni Abu, At Tuhfah, Beirut: Darul Fikr, 1994

Hajar, Ibni, Syaraha al Manhaj Lisyihab, Beirut: Darul Fikr, 1988.

Ibnu tayymiyah, al-Mustadrak 'ala Fatawa Syaikhil Islam, Beirut: Darul Fikri, 1987.

Khallaf, Abdul Wahab, Kaidah-Kaidah Fiqhi Islam, Cet III, Jakarta: PT. Raja Grafindo Persada, 2000.

Khallaf, Abdul Wahab, Kaidah Kaidah Hukum Islam, cet III , Jakarta: PT. Raja Grafindo Persada: 2000.

Kompilasi Hukum Islam, Jakarta :Depag RI, 2000.

Machfudh, Masduki, Bahstuln Masa'il diniyah, Malang: PPSH, 2000.

Mahfuz, Masduki, Bahsul masail, Malang: ppsnh, 2000.

Moloeng, Lexy J, Metodologi Penelitian Kualitatif, Cet 13, Bandung: Remeja Rasdakarya, 2001.

Mudjib, Abdul, Kaidah-Kaidah Ilmu Fiqih, Jakarta: kalam Mulia, 2001.

Nawawi, Imam, Syarah Al muazhab, Beirut: Darul Fikr, 1986.

Rasyid, Sulaiman, Ilmu fiqhi, Jakarta :Cv toha 1980.

Rasyid, Sulaiman, Ilmu fiqhi, Jakarta :Cv toha 1980.

Saleh, K. Wantjik, Hukum Perkawinan Indonesia, Jakarta Timur: Ghalia Indonesia, 1982.

Subekti, Hukum Keluarga dan Hukum Waris, Jakarta: Penerbit PT.Intermasa, 2002.

Syeikh ustaimin, Majmu’ Fatawa Lajnah Daimah, Madinah, 1992. 
Undang-Undang Nomor 1 Tahun 1974 tentang Perkawinan (LN 1974 Nomor 1,TLN 3019)

Usman, Muchlis, Kaidah-Kaidah Ushuliyah dan Fiqhiyah, (Jakarta: PT. Raja Grafindo Persada: 1999.

Wignjodipoere, Seorjono, Asas-asas Hukum Adat, Jakarta : Gunung Agung, 1988.

Yusuf bin Ibrahim, Al Anwar, Beirut: Daruh dihya, 2006. 